\title{
KLAIPĖDOS RAJONO SUAUGUSIŲJŲ GYVENTOJŲ SVEIKATOS VEIKSNIU NETOLYGUMAI
}

\author{
Neringa Tarvydiené $\dot{1}^{1}$ Monika Steponkiené $\dot{e}^{2}$, Faustas Stepukonis ${ }^{3}$, Sigutė Norkiené ${ }^{4}$ \\ ${ }^{l}$ Klaipédos rajono savivaldybès Visuomenès sveikatos biuras, Klaipédos universitetas, \\ ${ }^{2}$ Klaipèdos rajono savivaldybès Visuomenès sveikatos biuras, ${ }^{3}$ Klaipédos universitetas, \\ ${ }^{4} V_{s} I$ Klaipedos jūrininku ligonine, Klaipèdos universitetas
}

Raktažodžiai: sveikatos rizikos veiksniai, sveikatos netolygumai, gyvensena, socioekonominiai rodikliai.

\section{Santrauka}

Sveikatos netolygumus galima apibrèžti kaip gyventojų sveikatos būklès skirtumus tarp ịvairių grupių asmenų, kuriuos sąlygoja sveikatos determinantai. Gyvensena ir elgsena labiausiai nulemia žmogaus sveikatą. Klaipèdos rajone 2007, 2011, 2014 $\mathrm{m}$. buvo atlikti trys suaugusiųų gyventojų gyvensenos ir sveikatos tyrimai, kurių tikslas - nustatyti Klaipėdos rajono suaugusių gyventojų gyvensenos ir sveikatos netolygumus pagal socioekonominius rodiklius.

Apklausai atlikti buvo sudarytas klausimynas, remiantis „Suaugusių Lietuvos gyventojų gyvensenos tyrimo" klausimynu. Taikyta tikimybinè daugiapakopé atsitiktinè atranka. Apklausos atlikejjai kaimiškoje vietovejje atsitiktinai atrinktoje gatvejje nelyginiuose nuosavuose namuose (einant ị kas antrą namą) apklausė po vieną gyventoją, kurio gimtadienis yra arčiausiai. Miestuose atsitiktinai atrinktoje gatvejje apklausos atlikejjai rinkosi daugiabučius su nelyginiais namo numeriais, èjo ị kas antrą nelygini butą. Name arba bute buvo apklaustas ne daugiau kaip vienas gyventojas, vyresnis nei 18 metu, ir kurio gimtadienis yra arčiausiai.

Remiantis tyrimo rezultatais, kasdien ir kartais rūkančių gyventojų dalis sumažèjo 12,5 proc. nuo 2011 iki 2014 m. ir daržovių vartojimas mažiausiai 3 kartus per savaitę sumažèjo 39,9 proc. nuo 2007 m. iki $2014 \mathrm{~m}$. Tačiau alkoholinių gèrimų vartojimas Klaipėdos rajone du ir daugiau kartų per savaitę (padidejo 8,9 proc.), vaisių, uogų vartojimas padidejjo 30,1 proc., mankštinimasis mažiausiai 4 kartus per savaitę, padidejo 18,1 proc. Egzistuoja rūky- mo, alkoholinių gėrimų vartojimo, daržovių, vaisių, uogų valgymo ịpročių, fizinio aktyvumo netolygumai tarp suaugusių gyventojų pagal socioekonominius rodiklius - lytį, gyvenamają vietą, išsilavinimą, šeiminę padètí, užimtumą.

\section{Ivadas}

Pasaulio sveikatos organizacija sveikatą apibūdina kaip visišką fizinę, psichinę ir socialinę gerovę, o ne tik ligų ar negalios nebuvimą [1]. Laura McGovern ir kt. bendraautorių straipsnyje, Jolantos Valantienès ir kt. parengtose rekomendacijose nurodoma, jog gyvensena ir elgsena labiausiai nulemia žmogaus sveikatos būklę [2,3]. Sveikatos netolygumus (angl. health inequality) galima apibrèžti kaip gyventojų sveikatos būklès skirtumus tarp ịvairių grupių asmenų, kuriuos sąlygoja sveikatos determinantai. Sveikatos netolygumus iš dalies nulemia neišvengiami biologiniai veiksniai (amžius, lytis ir kt.) ir išvengiami, kurie atsiranda dèl paties žmogaus elgsenos, pasirinkto gyvenimo būdo [4, 5]. Didelès sveikatos rizikos grupèms yra priskiriami žemą išsilavinimą arba išsilavinimo neturintys asmenys, esantys žemo socioekonominio statuso, bedarbiai, išsiskyrę asmenys, neturintys nuolatinio užsièmimo, turintys mažas pajamas [6-9]. Remiantis $2014 \mathrm{~m}$. Lietuvoje atliktu suaugusių žmonių gyvensenos tyrimu, kuriame buvo nustatyti rūkymo skirtumai pagal sociodemografinius duomenis, kasdien rūkančių vyrų ir moterų dalis mažèja, tačiau buvo pastebèti skirtumai pagal išsilavinimą - daugiau kasdien rūké žemesnio išsilavinimo vyrai ir moterys nei turintys aukštajj išsilavinimą (2014 m. vyrai - 39 ir 26 proc., moterys - 17 ir 9 proc.). Per pastaruosius dvidešimt metų vyrų, kurie bent kartą per savaitę gèrè stiprius alkoholinius gèrimus, dalis 5 proc. sumažejo, o moterų nežymiai padidèjo -3 proc. Lietuvoje šviežiu daržovių vartojimas dideja, per du dešimtmečius vyrų daržovių vartojimas padidejjo 18 proc., o moteru - atitinkamai 28 proc. Nuo 1994 m. sportuojančiu 
asmenų dalis $30 \mathrm{~min} .4$ ir daugiau kartų per savaitę padidèjo beveik 2 kartus - 14 proc. vyrų ir 12 proc. moterų sportuoja daugiau [10].

Lietuvos Respublikos sveikatos apsaugos ministro 2014 m. liepos 16 d. Nr. V-815 patvirtintame Sveikatos netolygumų mažinimo Lietuvoje 2014-2023 m. veiksmų plane, sveikatos netolygumai apibrèžiami kaip ,diferenciacija tarp žmonių pagal sveikatos būklès (mirtingumo, būsimo gyvenimo trukmès rodikliai) skirtumus ir (ar) nevienodą sveikatos priežiūros paslaugų prieinamumą, kurị sąlygoja gyvenamoji vieta, pajamos ir kitos priežastys" [11]. Lietuvos Respublikos Seimo nutarimu patvirtintoje $2014 \mathrm{~m}$. birželio 26 d. Nr. XII-964 Lietuvos sveikatos programoje 2014-2025 m. strateginis tikslas - ,pasiekti, kad 2025 m. šalies gyventojai būtų sveikesni ir gyventų ilgiau, pagerètụ gyventojų sveikata ir sumažètu sveikatos netolygumai““ [12].

Tyrimo tikslas - nustatyti Klaipèdos rajono gyventojų gyvensenos ir sveikatos netolygumus pagal socioekonominius rodiklius.

\section{Tyrimo eiga ir metodai}

Klaipedos rajone 2007, 2011, $2014 \mathrm{~m}$. buvo atlikti trys suaugusiujų gyventojų gyvensenos ir sveikatos tyrimai. Buvo siekiama išanalizuoti Klaipedos rajono gyventojų elgseną (rūkymas, alkoholio vartojimas, mitybos ịpročiai, fizinis aktyvumas) pagal atitinkamus socialinius-ekonominius rodiklius - amžių, lytį, gyvenamają vietą, šeiminę padètị, išsilavinimą, darbą (veiklą/užimtumą). $2007 \mathrm{~m}$. tyrime dalyvavo 387 asmenys, kurių amžius siekè nuo 18 iki 87 metų, apklausta 58 proc. moterų ir 42 proc. vyrų. Anketų grįžtamumas - 97 proc. $2011 \mathrm{~m}$. tyrime dalyvavo 386 asmenys, kurių amžius siekè nuo 18 iki 64 metų, apklausta 57,5 proc. moteru ir 42,5 proc. vyrų. Anketų grįžtamumas - 100 proc. 2014 m. tyrime dalyvavo 394 asmenys, kurių amžius sieké nuo 18 iki 64 metų, apklausta 58,9 proc. moterų ir 41,1 proc. vyrų. Anketų grįžtamumas - 94,5 proc. Respondentų imtis buvo sudaryta remiantis 95 proc. pasikliovimo lygmeniu, pasirinkus 5 proc. paklaidą. Apklausai atlikti buvo sudarytas klausimynas, remiantis „Suaugusiu Lietuvos gyventojų gyvensenos tyrimo" klausimynu. Taikyta tikimybiné daugiapakopé atsitiktinè atranka. Apklausos atlikejai kaimiškoje vietoveje atsitiktinai atrinktoje gatvejje nelyginiuose nuosavuose namuose (einant ị kas antrą namą) apklausė po vieną gyventoją, kurio gimtadienis yra arčiausiai. Miestuose atsitiktinai atrinktoje gatvejje apklausos atlikejjai rinkosi daugiabučius su nelyginiais namo numeriais, èjo į kas antrą nelyginį butą. Name arba bute buvo apklaustas ne daugiau kaip vienas gyventojas, vyresnis nei 18 metų, ir kurio gimtadienis yra arčiausiai.
Statistinei duomenų analizei buvo naudojamas statistinių programų paketas SPSS 20.0 ir „MS Excel“ programa. Duomenu palyginimui taikytas chi kvadrato $\left(\chi^{2}\right)$ kriterijus. Rezultatai buvo vertinami kaip statistiškai reikšmingi, kai $\mathrm{p}<0,05$.

\section{Tyrimo rezultatai ir jų aptarimas}

Rūkymas (kasdien ir kartais). Klaipèdos rajone suaugusiujų rūkymas kiekvieną dieną ir kartais statistiškai reikšmingai sumažejo nuo 65 proc. (2007 m.) iki 60 proc. $(2014$ m.) $(\mathrm{p}<0,05)(1$ pav.). Tačiau analizuojant rūkymo situaciją pagal socialinius ekonominius rodiklius, pastebeti egzistuojantys sveikatos netolygumai.

Nuo 2007 m. sumažèjo rūkymo skirtumai tarp vyrų ir moterų, bet vyrai kiekvieną dieną ir kartais rūko daugiau nei moterys $(2014 \mathrm{~m} .60$ proc. ir 37,9 proc., $\mathrm{p}<0,05)(1$ pav.). Palyginus su 2007 m., 2014 m. sumažèjo rūkančiujjų skaičius 35 - $44 \mathrm{~m}$. amžiaus asmenų grupeje, nuo $2011 \mathrm{~m}$. mažèja $45-54$ m. amžiaus asmenų grupeje, tačiau rūkymas išaugo $25-34 \mathrm{~m}$. amžiaus asmenų grupejje $(\mathrm{p}<0,05)$. Nuo 2011 m. rūkymo skirtumai tarp miesto ir kaimo gyventojų ženkliai išaugo, $2014 \mathrm{~m}$. Klaipédos rajono miestuose 26,1 proc. buvo didesnè rūkančiųų dalis nei kaimuose ( $<<0,001$ ) (2 pav.). Nuo $2011 \mathrm{~m}$. dideja pradinị, pagrindini išsilavinimą turinčių asmenų dalis, kurie kasdien ir kartais rūko (2014 m. rūkè net 71,2 proc., $\mathrm{p}<0,05)$. 34,6 proc. padidejjo rūkymo skirtumai tarp aukštaji ir pradini, pagrindinį išsilavinimą turinčių asmenų - daugiau rūko pradinị, pagrindinị išsilavinimą turintys asmenys. Tarp aukštaji ir vidurinị išsilavinimą turinčių asmenų rūkymo skirtumas padidèjo 23,2 proc. - daugiau rūko vidurinị išsilavinimą turintys asmenys. 11,2 proc. sumažèjo rūkymo skirtumai tarp vidurinị ir pradinị, pagrindinị išsilavinimą turinčių asmenų (3 pav.). 12,8 proc. padidejjo rūkymo skirtumai tarp išsiskyrusių, našlių ir nevedusių - daugiau rūko išsiskyrę, našliai gyventojai ( $2014 \mathrm{~m}$. 53,3 proc.) bei 5,9 proc. padidejo rūkymo skirtumai tarp vedusių, gyvenančių nesusituokus ir išsiskyrusių, našlių. Tačiau 6,9 proc. sumažèjo rūkymo skirtumai tarp nevedusių ir vedusių, gyvenančių nesusituokus - (4 pav.). Daugiausia rūko nedirbantys asmenys, iskaitant studentus, namų šeimininkes, pensininkus (2014 $\mathrm{m}$. sudarė 53 proc.), mažiausiai rūko sèdimą darbą dirbantys gyventojai (2014 m. sudare 29,1 proc.) ( $<<0,05)$. 23,9 proc. padidèjo rūkymo skirtumai tarp nedirbančių ir sèdimą darbą dirbančių asmenų (5 pav.).

Bet kokio alkoholio vartojimas (du ir daugiau kartu per savaitę). Klaipedos rajone alkoholinių gėrimų vartojimas du ir daugiau kartų per savaitę nuo $2011 \mathrm{~m}$. statistiškai reikšmingai didejja $(\mathrm{p}<0,05)(6$ pav.). Nustatyti alkoholio vartojimo skirtumai pagal socioekonominius rodiklius. 
48 proc. padidèjo alkoholio vartojimo skirtumai tarp vyrų ir moterų, nustatyta, jog vyrai alkoholį vartoja daugiau nei moterys ( $2014 \mathrm{~m}$. 60,5 proc. ir 12,5 proc., $\mathrm{p}<0,0001)$ (6 pav.). $2014 \mathrm{~m}$. daugiausia alkoholị vartojo 2 ir daugiau kartų per savaitę jaunimas iki $24 \mathrm{~m}$. - kas antras Klaipedos rajono gyventojas ir tai turi tendenciją didèti. Pastebimi padidejję alkoholio vartojimo skirtumai tarp miesto ir kaimo gyventojų, daugiau išgeria miesto gyventojai, skirtumai nuo $2011 \mathrm{~m}$. didèja $(\mathrm{p}<0,05)(7 \mathrm{pav}$.). Daugiausia alkoholinius gèrimus vartoja pradinį, pagrindinị išsilavinimą turintys

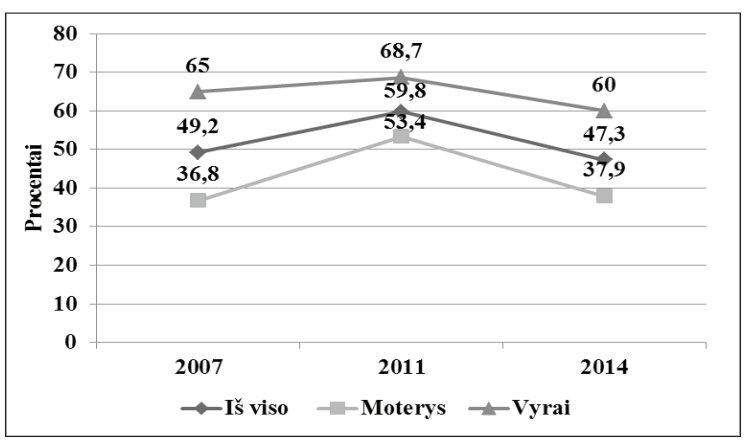

1 pav. Respondentų rūkymas kasdien ir kartais pagal lyti (proc.)

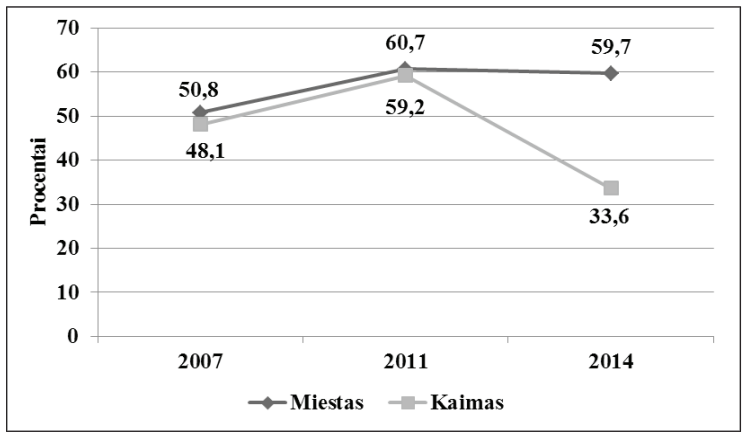

2 pav. Respondentų rūkymas kasdien ir kartais pagal gyvenamają vietą (proc.)

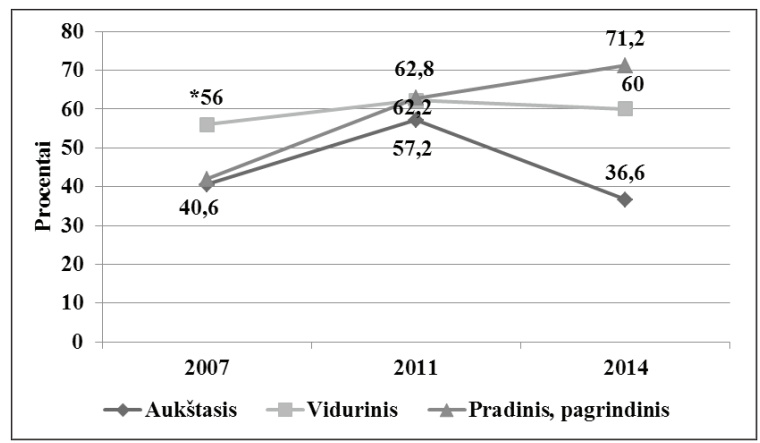

3 pav. Respondentų rūkymas kasdien ir kartais pagal išsilavinimą (proc.) asmenys, skirtumai turi tendenciją didèti (2014 m. sudarè 75,3 proc.). 2014 m. palyginus su $2011 \mathrm{~m}$., padidejjo alkoholị vartojančių asmenų dalis su viduriniu ir aukštuoju išsilavinimu. 52,3 proc. padidejo alkoholio vartojimo skirtumai tarp pradinį, pagrindinị ir vidurinị išsilavinimą turinčių asmenu ( $\mathrm{p}<0,05)$ (8 pav.). $2014 \mathrm{~m}$. ir $2011 \mathrm{~m}$. daugiausia alkoholị vartojo nevedę asmenys, skirtumai dideja (2014 m. sudare 41,1 proc., $p<0,05$ ). Didesni alkoholio vartojimo skirtumai nustatyti tarp vedusių, gyvenančiu nesusituokus

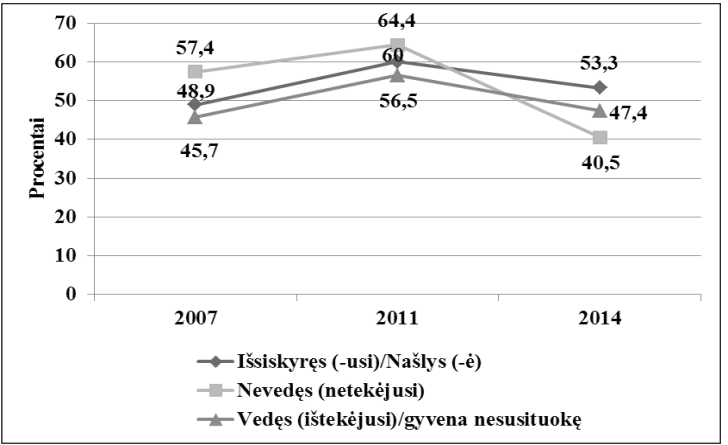

4 pav. Respondentų rūkymas kasdien ir kartais pagal šeiminę padèti (proc.)

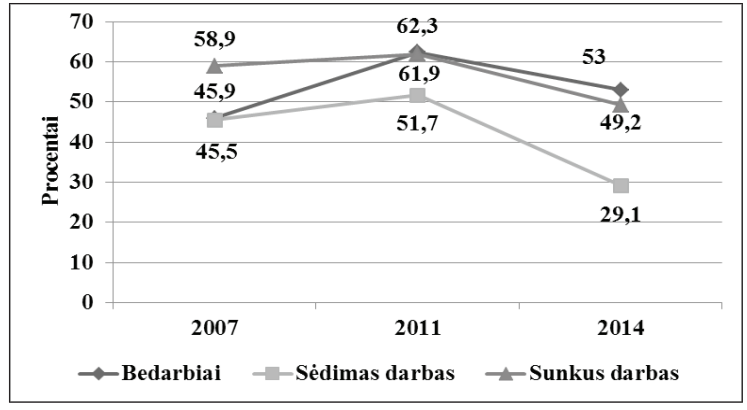

5 pav. Respondentų rūkymas kasdien ir kartais pagal užimtumą (proc.)

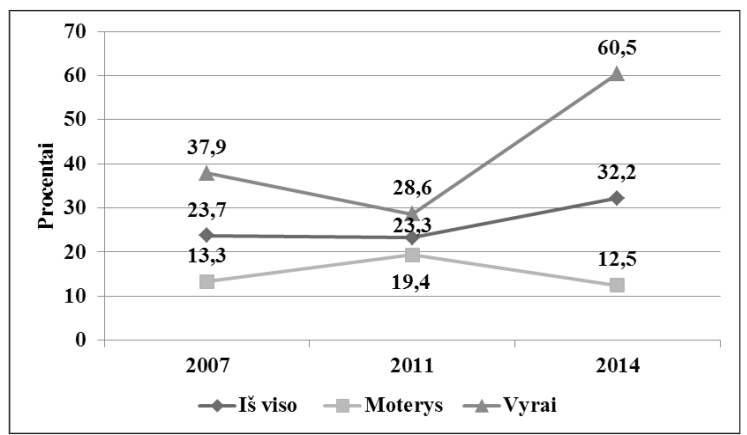

6 pav. Respondentų alkoholio vartojimas du ir daugiau kartų per savaitę pagal lytị (proc.) 


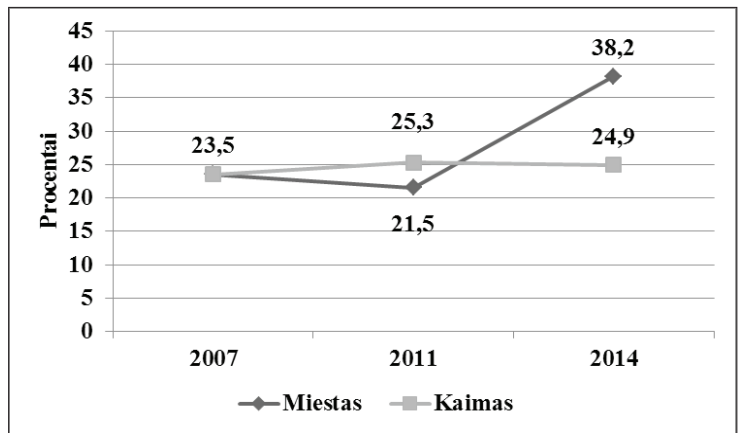

7 pav. Respondentų alkoholio vartojimas du ir daugiau kartų per savaitę pagal gyvenamąją vietą (proc.)

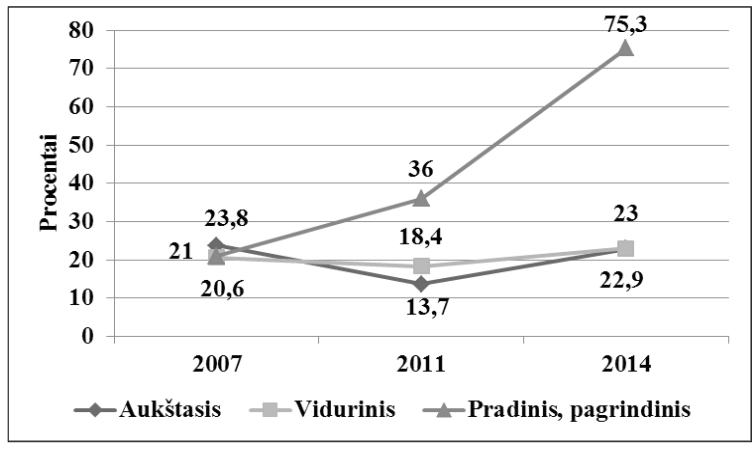

8 pav. Respondentų alkoholio vartojimas du ir daugiau kartų per savaitę pagal išsilavinimą(proc.)

ir nevedusių -9 proc., tarp išsiskyrusių, našlių ir nevedusių - 18 proc. (9 pav.). Paskutinio tyrimo duomenimis, statistiškai reikšmingai daugiausia alkoholị vartoja nedirbantys asmenys, įskaitant studentus, namų šeimininkes, pensininkus, mažiausiai - sėdimą darbą dirbantys $(\mathrm{p}<0,05)$. Nustatyti 20,8 proc. padideję alkoholio vartojimo skirtumai tarp sèdimą darbą dirbančių ir nedirbančių asmenų, bei sumažèjo tarp sunkų darbą dirbančių ir nedirbančių - 10 proc. 10,8 proc. sumažèjo alkoholio vartojimo skirtumas tarp sédimą ir sunkų darbą dirbančių asmenų (10 pav.).

Daržovių vartojimas mažiausiai 3 kartus per savaitę. Nuo 2007 m. Klaipedos rajone daržovių vartojimas mažiausiai 3 kartus per savaitę sumažèjo 39,9 proc. (11 pav.). Nustatyti daržovių vartojimo skirtumai pagal socioekonominius rodiklius.

Pastebimi statistiškai nereikšmingi daržovių vartojimo sumažèjimo skirtumai tarp moterų ir vyrų, tačiau moterys statistiškai reikšmingai daugiau vartoja daržoves nei vyrai $(\mathrm{p}<0,05)$ (11 pav.). $2014 \mathrm{~m}$. daugiausia daržoves vartojo 55-64 m. amžiaus gyventojai ir nuo $2011 \mathrm{~m}$. skirtumas turi tendenciją didèti. Sumažèjo daržovių vartojimo skirtumai tarp miesto ir kaimo gyventojų, tačiau 2014 m. palyginus su $2011 \mathrm{~m}$. daugiau daržoves vartoti pradèjo kaimo gy-

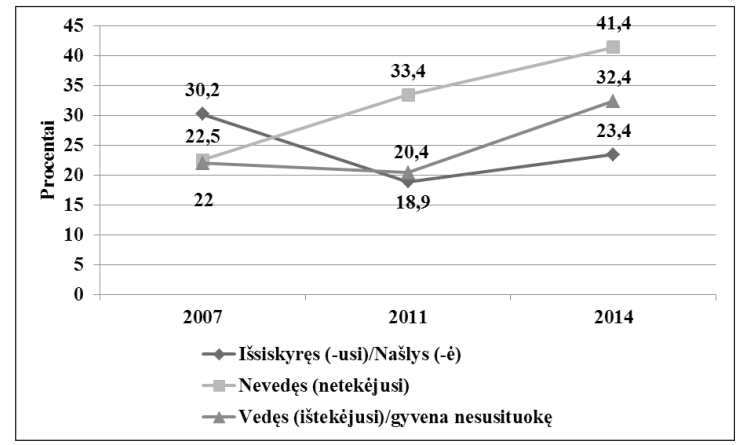

9 pav. Respondentų alkoholio vartojimas du ir daugiau kartų per savaitę pagal šeiminę padètį (proc.)

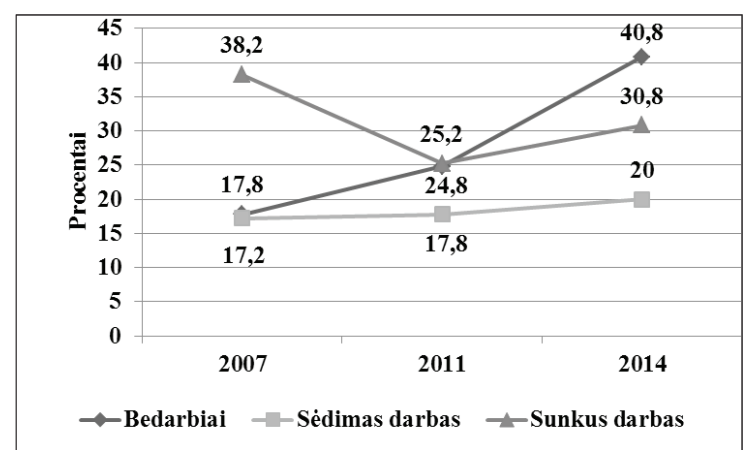

10 pav. Respondentų alkoholio vartojimas du ir daugiau kartų per savaitę pagal užimtumą(proc.)

ventojai (12 pav.). Pastebimi sumažèję daržovių vartojimo skirtumai tarp aukštaji ir pradinį, pagrindinị išsilavinimą turinčiu asmenų, 1,7 proc. asmenų su aukštuoju išsilavinimu daugiau vartoja daržoves. Tačiau padidejo daržovių vartojimo skirtumai tarp šių grupių: aukštajị ir vidurinị išsilavinimą turinčių asmenų, tarp pradinį, pagrindinị ir vidurinị išsilavinimą turinčių asmenų - daugiau daržoves vartoja vidurinị išsilavinimą turintys asmenys (13 pav.). 6,8 proc. sumažèjo daržovių vartojimo skirtumai tarp nevedusių ir vedusių, gyvenančių nesusituokus asmenų, daugiau daržoves vartoja nevedę asmenys. Tačiau 7,9 proc. padidèjo daržovių vartojimo skirtumai tarp išsiskyrusių, našlių ir nevedusių, 14,7 proc. tarp vedusių, gyvenančių nesusituokus ir išsiskyrusių, našlių - daugiau daržoves vartoja išsiskyrę, našliai (2014 m. 36,9 proc.) (14 pav.). 5,4 proc. sumažėjo daržovių vartojimo skirtumai tarp sunkų ir sėdimą darbą dirbančių asmenų, nuo 2007 m. daugiausia daržoves vartoja sėdimą darbą dirbantys asmenys. Tačiau padidejjo daržovių vartojimo skirtumai tarp nedirbančių ir sunkų darbą dirbančių asmenų, 13 proc. daugiau daržoves valgo sunkų darbą dirbantys asmenys, tarp nedirbančių ir sédimą darbą dirbančių, 18,4 proc. daugiau daržoves vartoja sėdimą dar- 


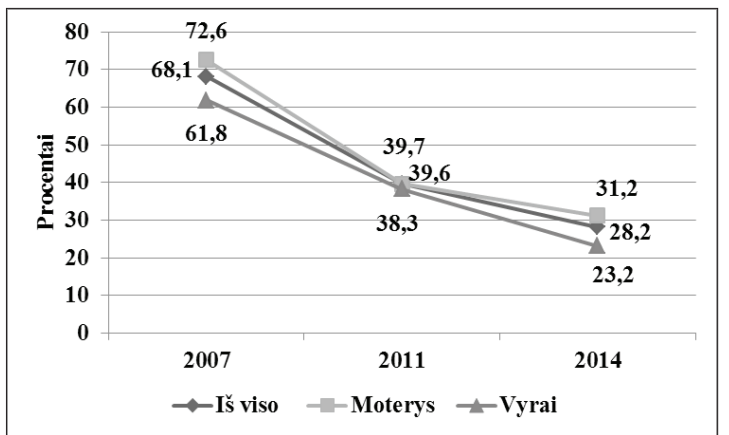

11 pav. Respondentų daržovių vartojimas mažiausiai 3 kartus per savaitę pagal lytị (proc.)

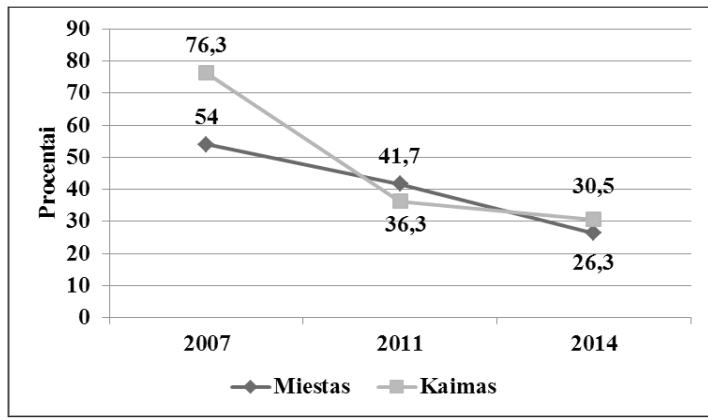

12 pav. Respondentų daržovių vartojimas mažiausiai 3 kartus per savaitę pagal gyvenamają vietą (proc.)

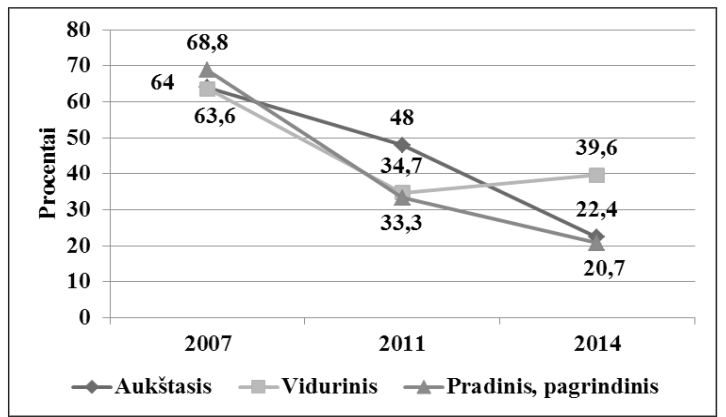

13 pav. Respondentų daržovių vartojimas mažiausiai 3 kartus per savaitę pagal išsilavinimą (proc.)

bą dirbantys asmenys (15 pav.).

Vaisių, uogų vartojimas mažiausiai 3 kartus per savaitę. Nuo $2011 \mathrm{~m}$. Klaipédos rajone vaisių, uogų vartojimas padidèjo 30,1 proc. (16 pav.). Tačiau išlieka vaisių, uogų vartojimo skirtumai pagal socioekonominius rodiklius.

Sumažèjo daržovių vartojimo skirtumai nuo 22,5 iki 9,9 proc. tarp vyrų ir moterų, vyrai pradejjo daugiau vartoti vaisius, uogas (2014 m. 64,2 proc.) (16 pav.). 2014 m. vaisius,

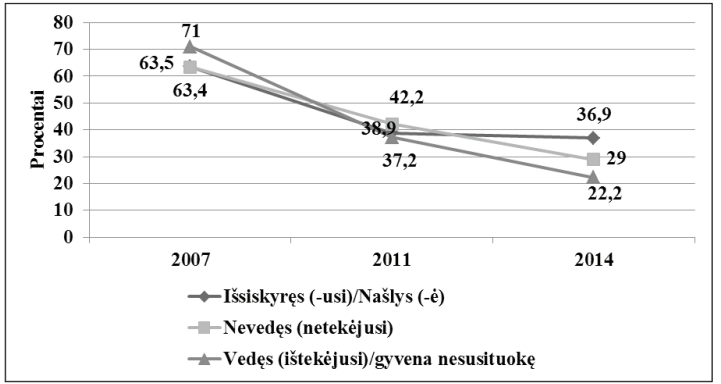

14 pav. Respondentų daržovių vartojimas mažiausiai 3 kartus per savaitę pagal šeiminę padètị (proc.)

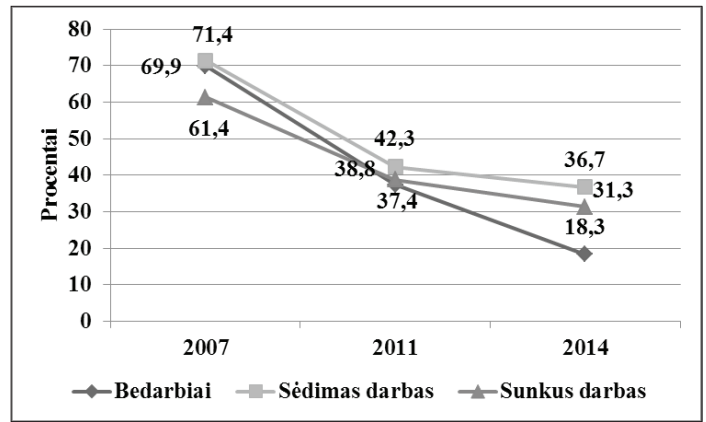

15 pav. Respondentų daržovių vartojimas mažiausiai 3 kartus per savaitę pagal užimtumą (proc.)

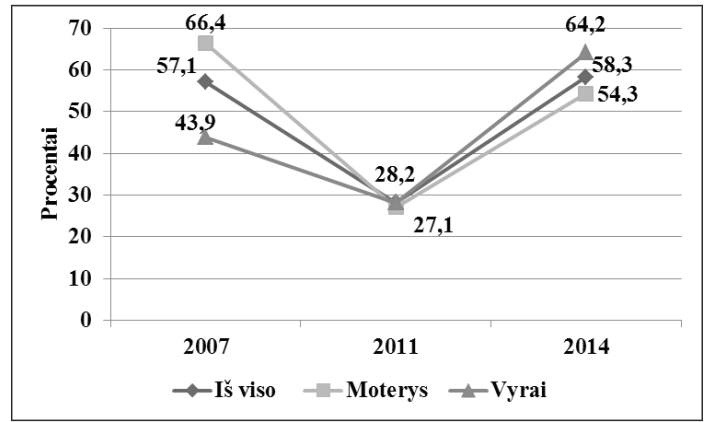

16 pav. Respondentų vaisių, uogų vartojimas mažiausiai 3 kartus per savaitę pagal lytị (proc.)

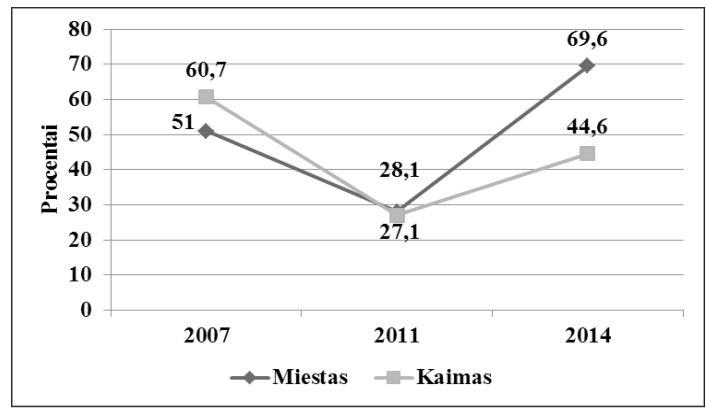

17 pav. Respondentų vaisių, uogų vartojimas mažiausiai 3 kartus per savaitę pagal gyvenamają vietą (proc.) 


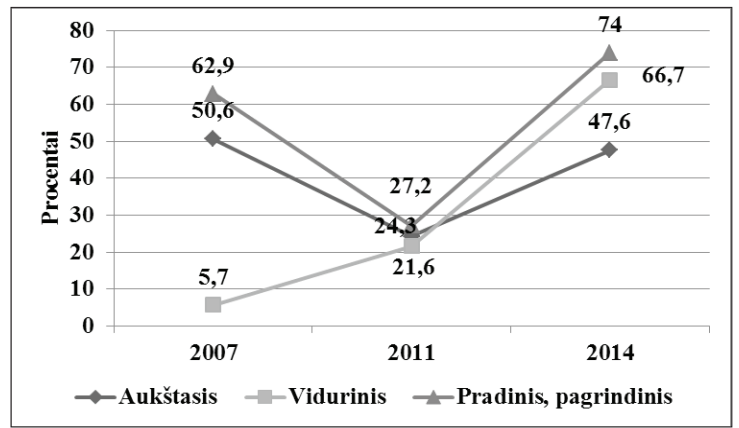

18 pav. Respondentų vaisių, uogų vartojimas mažiausiai 3 kartus per savaitę pagal išsilavinimą (proc.)

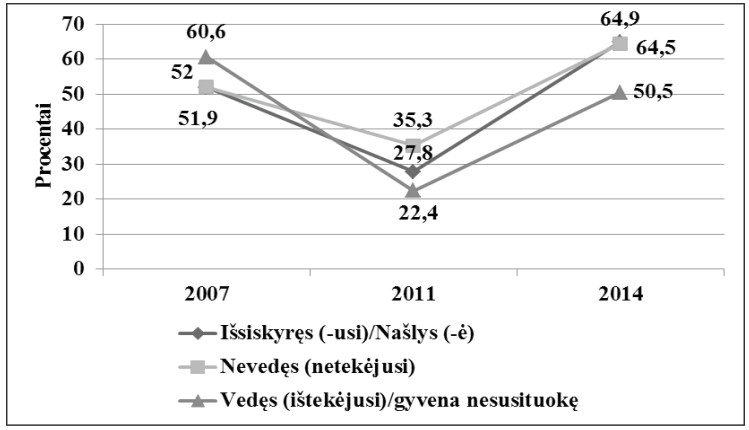

19 pav. Respondentų vaisių, uogų vartojimas mažiausiai 3 kartus per savaitę pagal šeiminę padètị (proc.)

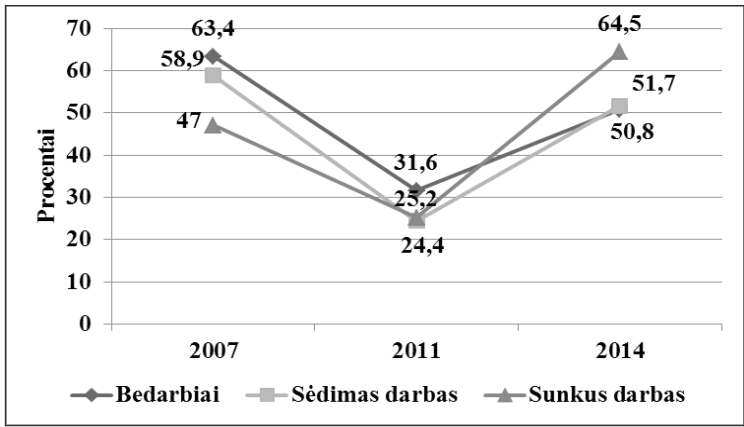

20 pav. Respondentų vaisių, uogų vartojimas mažiausiai 3 kartus per savaitę pagal užimtumą (proc.)

uogas daugiausia vartojo $45-54 \mathrm{~m}$. asmenys (67,5 proc.), mažiausiai - 55-64 m. gyventojai (44,4 proc.). Nustatyti 25 proc. padidejję vaisių, uogų vartojimo skirtumai tarp miesto ir kaimo gyventojų, 2014 m. palyginus su $2011 \mathrm{~m}$. ženkliai padidèjo vaisių, uogų vartojimas tarp miesto gyventojų (2014 m. 69,6 proc.) (17 pav.). Sumažèjo 7,3 proc. vaisių, uogų vartojimo skirtumai tarp pradini, pagrindinị ir vidurinị išsilavinimą turinčių asmenų, tačiau padidèjo vaisių, uogų vartojimo skirtumai tarp aukštajị ir pradinį, pagrindi-

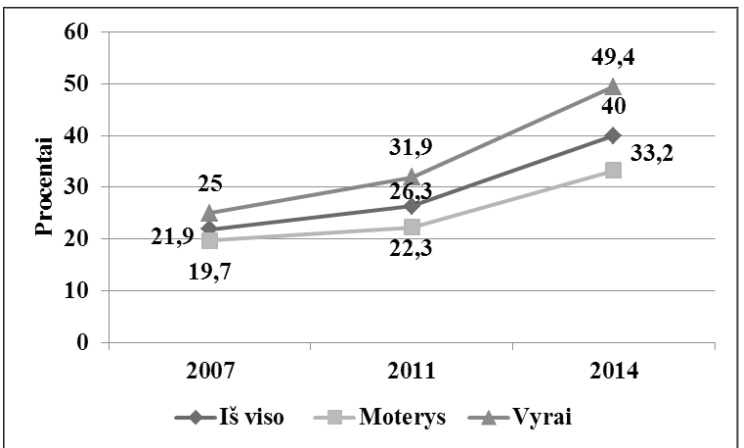

21 pav. Mankštinimasis mažiausiai $30 \mathrm{~min}$. taip, kad pagreitètų jų kvèpavimas pagal lytị (proc.)

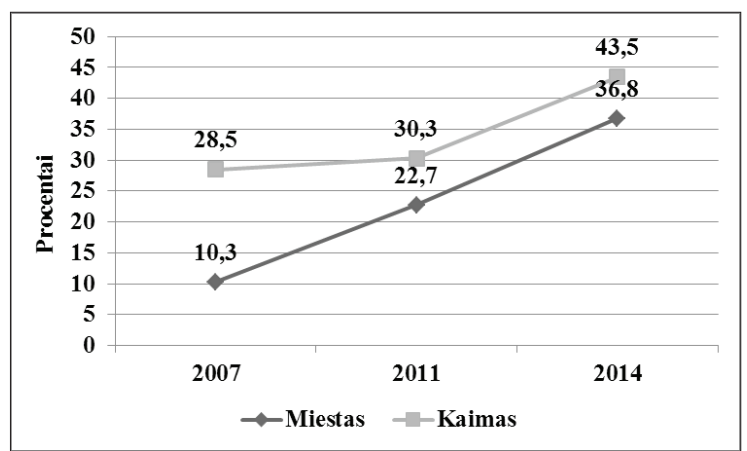

22 pav. Mankštinimasis mažiausiai 30 min. taip, kad pagreitėtų jų kvėpavimas pagal gyvenamąją vietą (proc.)

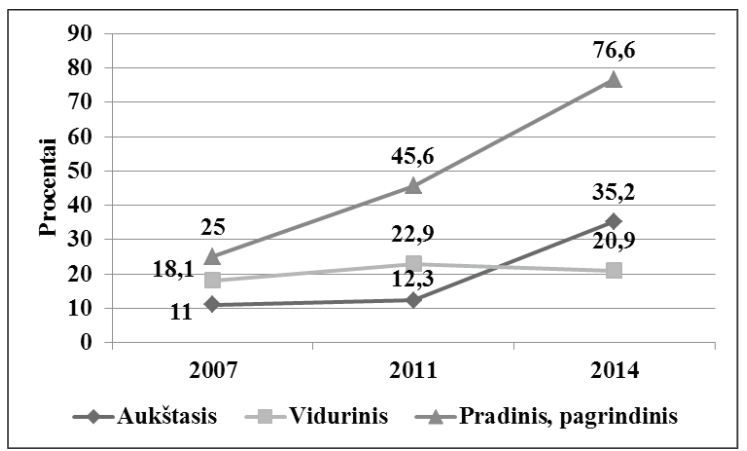

23 pav. Mankštinimasis mažiausiai 30 min. taip, kad pagreitètų jų kvejpavimas pagal išsilavinimą (proc.)

nị išsilavinimą turinčiu asmenų 26,4 proc., daugiau vaisius, uogas vartoja gyventojai, turintys pradini, pagrindinį išsilavinimą (2014 m. 74 proc.). Sumažèjo 19,1 proc. vaisių, uogų vartojimo skirtumai tarp vidurinį ir aukštaji išsilavinimą turinčių asmenų, daugiau vaisius ir uogas valgo vidurinį išsilavinimą turintys asmenys (2014 m. 66,7 proc.) (18 pav.). Padidejo vaisių, uogų vartojimo skirtumai nuo 8,7 iki 14,4 proc. tarp išsiskyrusių, našlių ir vedusių, gyvenan- 


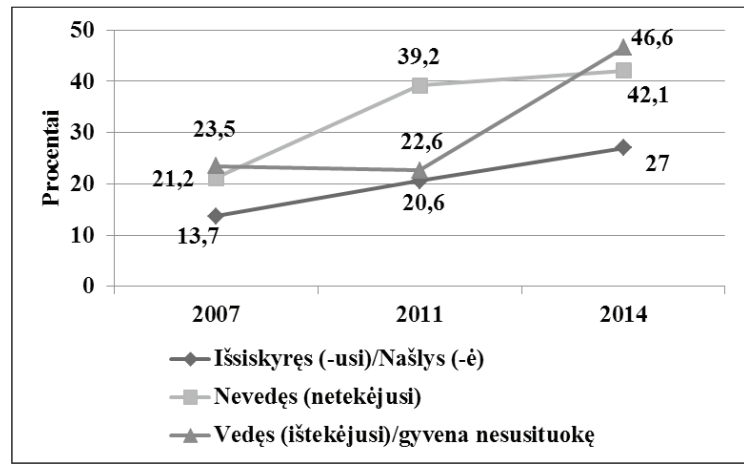

24 pav. Mankštinimasis mažiausiai 30 min. taip, kad pagreitètų jų kvėpavimas pagal šeiminę padètị (proc.)

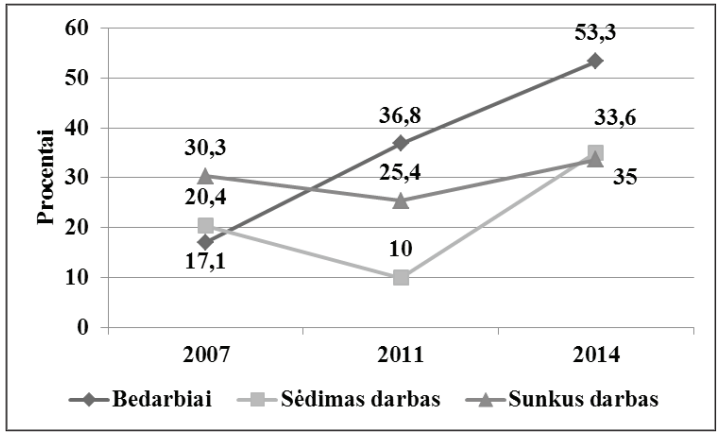

25 pav. Mankštinimasis mažiausiai $30 \mathrm{~min}$. taip, kad pagreitètų jų kvẻpavimas pagal užimtumą (proc.)

čių nesusituokus, daugiau vaisius ir uogas valgo išsiskyrę, našliai (2014 m. 64,9 proc.), nuo 8,6 iki 14 proc. tarp nevedusių ir vedusių, gyvenančių nesusituokus, daugiau vaisius, uogas vartoja nevedę (2014 m. 64,5 proc.). Padidèjo vaisiu, uogu vartojimo skirtumai nuo 8,6 iki 14 proc. tarp nevedusių ir vedusių, gyvenančių nesusituokus -daugiau vaisius, uogas vartoja nevedę ( $2014 \mathrm{~m}$. 64,5 proc.); nuo 8,7 iki 14,4 proc. tarp išsiskyrusių, našlių ir vedusių, gyvenančių nesusituokus - daugiau vaisius, uogas vartoja išsiskyrę, našliai (2014 m. 64,9 proc.) (19 pav.). Sumažèjo vaisių, uogų vartojimo skirtumai tarp nedirbančių ir sédimą darbą dirbančių asmenų, daugiau daržoves vartoja sẻdimą darbą dirbantys asmenys (2014 m. 51,7 proc.). Sumažèjo daržovių vartojimo skirtumai tarp nedirbančių ir sunkų darbą dirbančių asmenų, tačiau padidèjo nuo 11,9 iki 12,8 proc. tarp sẻdimą ir sunkų darbą dirbančių asmenų, daugiau vaisius, uogas vartoja sunkų darbą dirbantys gyventojai (2014 m. 64,5 proc.) (20 pav.).

Mankštinimasis mažiausiai 4 kartus per savaitę. 2014 m. kas antras Klaipedos rajono gyventojas mankštinasi mažiausiai 4 kartus per savaitę ir sportuojančių gyventojų dalis didejja (21 pav.). Tačiau egzistuoja mankštinimosi mažiausiai 4 kartus per savaitę (toliau -sportuojančių) netolygumai pagal socioekonominius duomenis.

Nustatyti 16,2 proc. padidèję sportuojančių asmenų skirtumai tarp vyrų ir moterų, nuo $2007 \mathrm{~m}$. vyrai sportuoja daugiau (2014 m. 49,4 proc.) (21 pav.). $2014 \mathrm{~m}$. daugiausia mankštinasi jaunimas iki $24 \mathrm{~m}$. ir 55-64 m. asmenys (54,5 ir 55,5 proc.). 6,7 proc. sumažejo sportavimo skirtumai tarp miesto ir kaimo gyventojų, nuo $2007 \mathrm{~m}$. kaimo gyventojai mankštinasi daugiau (2014 m. 43,5 proc.) (22 pav.). 55,7 proc. padidejo sportavimo skirtumai tarp pradinị, pagrindinị ir vidurinį išsilavinimą turinčių asmenų, 41,4 proc. tarp pradinį, pagrindinị ir aukštajị išsilavinimą turinčių asmenų, daugiau sportuoja asmenys, kurie turi pradini, pagrindini išsilavinimą (2014 m. 76,6 proc.). Padidejo sportuojančių asmenų skirtumai tarp aukštajjị ir vidurinị išsilavinimą turinčių asmenų, daugiau sportuoja turintys aukštajj išsilavinimą (2014 m. 35,2 proc.) (23 pav.). Padidejjo sportuojančiu asmenų skirtumai tarp nevedusių ir vedusių, gyvenančių nesusituokus; tarp išsiskyrusių, našlių ir vedusių, gyvenančių nesusituokus, daugiau mankštinasi vedę, gyvenantys nesusituokus (2014 m. 46,6 proc.); tarp nevedusių ir išsiskyrusių, našlių, daugiau mankštinasi nevedę (2014 m. 42,1 proc.) (24 pav.). 18,3 proc. padidejo sportavimo skirtumai tarp nedirbančių ir sèdimą darbą dirbančių asmenų; 19,7 proc. tarp sunkų darbą dirbančių ir nedirbančių, daugiausia sportu užsiima nedirbantys asmenys $(2014 \mathrm{~m}$. 53,3 proc.). Sumažejo skirtumas tarp sėdimą ir sunkų darbą dirbančių asmenų (25 pav.).

\section{Išvados}

1. Nuo $2011 \mathrm{~m}$. iki $2014 \mathrm{~m}$. Klaipèdos rajone 12,5 proc. sumažèjo rūkančiųjų kasdien ir kartais gyventojų dalis $(\mathrm{p}<0,05)$, nuo $2007 \mathrm{~m}$. iki $2014 \mathrm{~m}$. sumažèjo 39,9 proc. daržovių vartojimas mažiausiai 3 kartus per savaitę.

2. Nuo $2011 \mathrm{~m}$. iki $2014 \mathrm{~m}$. alkoholiniu gėrimų vartojimas Klaipedos rajone du ir daugiau kartų per savaitę padidejjo 8,9 proc., vaisių, uogų vartojimas padidejo 30,1 proc., mankštinasi mažiausiai 4 kartus per savaitę padidèjo 18,1 proc. (nuo $2007 \mathrm{~m}$.).

3. Egzistuoja rūkymo, alkoholinių gèrimų vartojimo, daržovių, vaisių, uogų valgymo ịpročių, fizinio aktyvumo netolygumai tarp suaugusių gyventojų pagal socioekonominius rodiklius - lyti, gyvenamąą vietą, išsilavinimą, šeiminę padètí, užimtumą

\section{Literatūra}

1. WHO. Constitution of the World Health Organization. Geneva: World Health Organization. 1948.

2. Mc Govern L., Miller G., Hughes-Cromwick P. Health Policy Brief: The relative contribution of multiple determinants to 
health outcomes. Health Affairs 2014: 4-5.

3. Valentienè J., Nedzinskienè L., Liuima V. ir kt. Sveikatos netolygumų stebėsena ir vertinimas. Metodinès rekomendacijos. Vilnius, 2016.

4. Kawachi I. A glossary for health inequalities. Journal of Epidemiology and Community Health 2002; 56(9): 647. https://doi.org/10.1136/jech.56.9.647

5. WHO. Health Impact Assessment (HIA) Glossary of terms. Prieiga per Internetą: http://www.who.int/hia/about/glos/en/ index 1.html.

6. Lazzarino AI, Yiengprugsawan V, Seubsman SA. et al. The associations between unhealthy behaviours, mental stress, and low socio-economic status in an international comparison of representative samples from Thailand and England. Globalization And Health 2014; 10:10.

https://doi.org/10.1186/1744-8603-10-10

7. Movsisyan NK, Sochor O, Kralikova E. et al. Current and past smoking patterns in a Central European urban population: a cross-sectional study in a high-burden country. BMC Public Healt 2016; 16: 571.

https://doi.org/10.1186/s12889-016-3216-5

8. Palipudi KM, Sinha DN, Choudhury S. et al. Predictors of tobacco smoking and smokeless tobacco use among adults in Bangladesh. Indian Journal Of Cancer 2012; 49 (4): 387-92. https://doi.org/10.4103/0019-509X.107745

9. Alcohol consumption in middle-aged adults is associated with poorer cognitive performance only in the low socio-economic group. Results from the GAZEL cohort study. Addiction 2011; 106: 93-101. https://doi.org/10.1111/j.1360-0443.2010.03106.x

10. Grabauskas V., Klumbienė J., Petkevičienė J. ir kt. Suaugusių Lietuvos žmonių gyvensenos tyrimas. Kaunas, 2014.

11. Dèl sveikatos netolygumų mažinimo Lietuvoje 2014-2023 m. veiksmų plano patvirtinimo": Lietuvos Respublikos sveikatos apsaugos ministro $2014 \mathrm{~m}$. liepos $17 \mathrm{~d}$. įsakymas Nr. V-815.

12. Dèl Lietuvos sveikatos 2014-2025 metų programos patvirtini- mo": Lietuvos Respublikos Seimo nutarimas 2014 m. birželio 26 d. Nr. XII-964.

\section{ADULT POPULATION HEALTH FACTORS INEQUALITY IN KLAIPEDA REGION}

N. Tarvydienė, M. Steponkienė, F. Stepukonis, S. Norkienė

Key words: health risk factors, health inequality, lifestyle, socio-economic indicators.

Summary

Health inequality can be defined as the state of health of the population differences among the various groups of people, which leads health determinants. Human health the most dependent of lifestyle and behaviour. In 2007, 2011 and in 2014 year were performed three of the adult population lifestyle and health research in Klaipeda region, which aim - to set the adult population lifestyle and health inequality by socio-economic indicators in Klaipeda region. The questionnaire was concluded on the basis of adult Lithuanian population lifestyle survey questionnaire. In the study was used a multi-stage probability random selection. Researcher in rural areas randomly chosen street odd houses and interviewed adult whose birthday is closest. Researcher in cities randomly chosen street blocks with odd house numbers, went to every other odd accommodation and interviewed adult whose birthday is closest. According to the survey results, daily and sometimes smoking in the population decreased 12,5 percent from 2011 to 2014 and consumption of vegetables at least 3 times a week decreased 39,9 percent from 2007 to 2014. However, consumption of alcoholic beverages two or more times a week increased by 8,9 percent, fruit consumption increased by 30,1 percent, playing sports at least 4 times a week increased by 18,1 percent in Klaipeda region. There are smoking, consumption of alcoholic beverages, vegetables, fruits, eating habits, physical activity inequality among the adult population of socio-economic indicators - sex, residence, education, marital status, employment.

Correspondence to:

monika.steponkiene@visuomenessveikata.lt

Gauta 2016-10-27 